УДК 636.087.24; 663.48

\title{
ИССЛЕДОВАНИЕ ПО ПОЛУЧЕНИЮ И ПРИМЕНЕНИЮ БЕЛКОВОГО ГИДРОЛИЗАТА ИЗ ОСТАТОЧНЫХ ПИВНЫХ ДРОЖЖЕЙ В ТЕХНОЛОГИИ ЗЛАКОВЫХ БАТОНЧИКОВ
}

\author{
Е. А. Казимирова, О. Я. Мезенова, В. И. Шендерюк
}

\section{RESEARCH ON THE PREPARATION AND APPLICATION OF PROTEIN HYDROLYSATE FROM RESIDUAL BREWER'S YEAST IN CEREAL BAR TECHNOLOGY}

\author{
E. A. Kazimirova, O. Ya. Mezenova, V. I. Shenderyuk
}

Изучен биопотенциал остаточных пивных дрожжей и пивной дробины (отходов пивоваренного производства), обосновано получение белковых гидролизатов из дрожжей и их применение в технологии злаковых батончиков. Проведен анализ научно-технической литературы по применению вторичного сырья пивоваренных производств. Изучен общий химический состав остаточных дрожжей и пивной дробины, предоставленных пивоварней «Редюит». Проанализирован аминокислотный состав белка и рассчитана биологическая ценность пивных дрожжей. Исследованы ферментативный и высокотемпературный термический способы гидролиза остаточных пивных дрожжей. Изучена природа горечей пивных дрожжей и степень ее вкусового проявления. Определено количество горечи в остаточных пивных дрожжах в зависимости от промывки их водой. Выявлены зависимости влияния хмелевой горечи пивных дрожжей на степень их гидролиза. Опытным путем установлена рациональная технология производства белкового гидролизата с применением высокотемпературного гидролиза. Остаточные пивные дрожжи являются источником многих биологически активных веществ, прежде всего, белка и незаменимых аминокислот, витаминов группы В и различных макро- и микронутриентов. Пивная дробина содержит высокое количество клетчатки, белка, витамина Е и витаминов группы В, минеральных веществ и других биологически активных веществ. Показана рациональность применения белкового гидролизата дрожжей в качестве белковой добавки в рецептуре злакового батончика на основе пивной дробины. Определен общий химический состав обогащенных злаковых батончиков. Разработанные злаковые батончики имеют повышенную пищевую ценность по содержанию белка и пищевых волокон и рекомендованы к употреблению всем группам населения, а также для профилактики заболеваний желудочно-кишечного тракта.

отходы пивоваренного производства, остаточные пивные дрожжи, пивная дробина, белковый гидролизат, злаковый батончик, БАВ

We have studied the biopotential of the residual brewer's yeast and brewer pellet (waste from the brewing industry) to produce protein hydrolysates and their applications in technologies for cereal bars. The analysis has been conducted of scientific and technical literature on the use of secondary raw materials of brewing industries. General 
chemical composition of residual yeast and brewer pellets provided by the brewery "Reduit" has been studied. The amino acid composition of protein has been analyzed and the biological value of brewer's yeast has been calculated. Enzymatic and hightemperature thermal methods of hydrolysis of residual brewer's yeast have been investigated. The nature of bitterness of brewer's yeast and the degree of its flavor release have been studied. The amount of bitterness in residual brewer's yeast has been determined depending on their washing with water. Dependences of influence of hop bitterness of brewer's yeast on the degree of their hydrolysis have been revealed. The rational technology of protein hydrolysate production using high-temperature hydrolysis has been experimentally established. Residual brewer's yeast is a source of many biologically active substances, primarily protein and essential amino acids, b vitamins and various macro - and micronutrients. Brewer pellets contain high amounts of fiber, protein, vita$\min \mathrm{E}$ and $\mathrm{b}$ vitamins, minerals and other biologically active substances. Rationality of the use of white yeast hydrolysate as a protein additive in the formulation of a cereal bar based on brewer pellets has been shown. General chemical composition of enriched cereal bars has been determined. The developed cereal bars have a higher nutritional value in terms of protein and dietary fiber and are recommended for use by all groups of the population, as well as for the prevention of diseases of the gastrointestinal tract. al bar, BAS

brewing waste, residual brewer's yeast, brewer pellet, protein hydrolysate, cere-

\section{ВВЕДЕНИЕ}

Основой экономики Калининградской области является промышленность, в которой доминирующее положение занимает пищевая отрасль, в том числе пивоваренное производство. На территории области насчитывается около 35 пивоварен различной производительности. Главными отходами пивоваренных производств являются остаточные пивные дрожжи и пивная дробина, которые образуются в очень больших количествах и практически не перерабатываются. При выпуске 500 л пива образуется в качестве отходов 110-120 кг пивной дробины и около 40-45 кг пивных дрожжей, при этом только 30 \% дрожжей используются для дальнейших циклов брожения пива. За счет высокой влажности данные отходы быстро портятся, поэтому в основном их утилизируют, и только некоторая часть пивной дробины идет на корм животным.

Остаточные пивные дрожжи представляют собой ценнейших источник белка со сбалансированным содержанием незаменимых аминокислот, витаминов группы В, нуклеиновых кислот, а также макро- и микронутриентов. Пивная дробина сочетает в себе ценные органические и неорганические биологически активные вещества, содержит большое количество клетчатки, белка, витамина Е, витаминов группы В и минеральных веществ [1].

Одним из актуальных вопросов настоящего дня являются недостаток полноценного белка в питании и связанный с этим рост различных заболеваний. В перечне обусловленных этим болезней лидируют заболевания желудочнокишечного тракта, наблюдаемые практически у всех групп населения. Поэтому целесообразно разрабатывать новые виды белковой продукции с применением таких ценных источников белковых веществ, как пивная дробина и дрожжи. 
Злаковые батончики в последние годы пользуются повышенной популярностью у всех групп населений, особенно у молодежи. Их употребляют в качестве перекуса и десерта в течение дня, используют как энергетический продукт. Однако в традиционном составе батончиков преобладают углеводы, представленные простыми сахарами, практически отсутствуют белки и сложные углеводы. Чтобы получить сбалансированный по составу и полезный калорийный продукт с высокими органолептическими свойствами предлагается заменить часть основного сырья (овсяной крупы) злакового батончика на пивную дробину и белковый гидролизат остаточных пивных дрожжей. Это позволит обогатить изделие клетчаткой, растительными белками, БАВ-ми зерновых культур и пивных дрожжей, что в итоге приведет к повышению содержания белка и аминокислотной сбалансированности готового батончика.

Анализ патентных и научно-технических источников показал, что за последние два десятилетия актуальны и перспективны разработки по рациональному использованию вторичного сырья, внедрению безотходных технологии переработки природных ресурсов, получению белковых добавок и их использованию для обогащения пищевых продуктов белком [2].

В России и других странах остаточные пивные дрожжи используют в основном при производстве белковых кормовых добавок. Также из остаточных пивных дрожжей выделяют фермент инвертазу (b-фруктофуранозидазу), который используют для гидролиза сахарозы. Но чаще всего остаточные дрожжи смывают в канализацию или утилизируют другими способами.

Пивная дробина также используется в основном в кормовом производстве, но все чаще ее рассматривают в качестве пищевой добавки к пище и функционального ингредиента в хлебопечении, кондитерской промышленности, в составе мясных колбас. Например, обосновано применение обогатителя из остаточных пивных дрожжей и пивной дробины в технологии получения ржано-пшеничного хлеба, показано повышение пищевой ценности хлеба [3]. Доказана актуальность введения остаточных пивных дрожжей в рецептуру хлеба в качестве ингибитора, замедляющего процесс его черствения [4]. Предложена технология получения и применения автолизата пивных дрожжей в производстве вареных колбас [5].

Таким образом, отходы пивоваренных производств являются перспективным сырьем для улучшения качественных характеристик многих продуктов. Поэтому разработка злаковых батончиков на основе вторичного сырья пивоваренных производств является актуальной и практически значимой.

Цель работы заключалась в установлении рационального способа получения белкового гидролизата остаточных пивных дрожжей и обоснование дальнейшего его применения при производстве злаковых батончиков на основе пивной дробины. Для этого изучали биопотенциал остаточных пивных дрожжей и дробины, исследовали различные способы их гидролиза и качество полученных белковых гидролизатов, изучали химический состав конечной продукции.

\section{ОБЪЕКТЫ И МЕТОДЫ ИССЛЕДОВАНИЯ}

Объектами исследования являлись остаточные пивные дрожжи рода и вида Saccharomyces carlsbergensis (низового брожения) и пивная дробина, предоставленные для исследования малой пивоварней «Редюит» (г. Калининград). а также злаковые батончики на их основе. Остаточные пивные дрожжи исследовали после 
первой, третьей и шестой варок пива. Пивная дробина представляла собой густую смесь дробленых зерен ячменя и пшеницы, оставшуюся после варки и отсасывания сусла, с частицами ядер и оболочек зерна. Злаковые батончики на основе пивной дробины готовились по авторской рецептуре на основе овсяных хлопьев.

Для получения белковой добавки пивные дрожжи предварительно гидролизовали, что позволило сконцентрировать белковую фракцию, удалить небелковую и вещества-горечи. Для этого использовали ферментативный $\left(\mathrm{T}=49-52^{0} \mathrm{C}\right.$, $\tau=4,5$ ч) способ гидролиза с применением протеаз, а также термический высокотемпературный гидролиз $\left(\mathrm{T}=130^{\circ} \mathrm{C}, \tau=1 \mathrm{q}\right)$, проводимый в специальном термореакторе при повышенном давлении (3-6 бар). Ферментативный гидролиз выполняли с применением двух ферментных препаратов: «Alcalase ${ }^{\circledR} » 2,5$ L (активность 2,5 AU/г) и «Protomex» (производство фирмы «Novozymes», Дания, активность 2,5 AU/г). Химический состав сырья и готовой продукции определяли по ГОСТ 7636. Оценку степени гидролиза проводили методом формольного титрования по количеству накопленного аминного азота. Для определения белка использовали классический метод Кьельдаля, массовую долю жира оценивали экстракционным способом на приборе Сокслета, а содержание минеральных веществ устанавливали массовым методом на основе высокотемпературного способа минерализации.

\section{ИССЛЕДОВАТЕЛЬСКАЯ ЧАСТЬ}

Установлено, что белок пивных дрожжей сбалансирован по содержанию аминокислот, но плохо усваивается организмом человека за счет высокой устойчивости клеточных оболочек дрожжей к воздействию пищеварительных ферментов [6]. Гидролиз дрожжей позволяет разрушить клеточную стенку дрожжевой клетки и выделить легкоусвояемые белковые вещества. Общий химический состав остаточных пивных дрожжей приведен в табл. 1.

Таблица 1. Химический состав остаточных пивных дрожжей, \%

Table 1. Chemical composition of residual brewer's yeast

\begin{tabular}{|l|c|c|c|c|}
\hline $\begin{array}{c}\text { Дата взятия образца } \\
\text { с пивоварни «Редюит» }\end{array}$ & Белок & Жиры & Углеводы & $\begin{array}{c}\text { Минеральные } \\
\text { вещества }\end{array}$ \\
\hline 20.02 .2019 (6-я варка) & 62,0 & 2,7 & 27,1 & 8,2 \\
\hline 22.04 .2019 (1-я варка) & 57,6 & 2.6 & 32,6 & 7,2 \\
\hline 18.06 .2019 (3-я варка) & 59,3 & 3,2 & 29,8 & 7,7 \\
\hline
\end{tabular}

Из данных табл. 1 видно, что химический состав пивных дрожжей зависит от их физиологического состояния, при этом содержание белка и минеральных веществ в сухом веществе остаточных пивных дрожжей довольно высокое и может достигать по белку 57,6-62,0 \%, а по минеральным веществам 7,2-8,2 \%. Существенно для оценки пищевой ценности, что дрожжи богаты углеводами $(27,1$ 32,6 \%), представленными в основном гликогеном, при этом в них относительно мало жира (2,6-3,2 \%), что обусловливает их хранимоспособность.

Содержание незаменимых аминокислот в белках дрожжей, рассчитанное относительно «идеального» белка скоры, и показатель биологической ценности белка представлены в табл. 2. Лимитирующими аминокислотами являются трео- 
нин (26,0 \%) и лейцин (скор 33,4 \%), но дрожжи богаты лизином (скор 114,9 \%), фенилаланином и тирозином (скор 104,7 \%), метионином и цистином (103,9 \%).

Таблица 2. Содержание незаменимых аминокислот и биологическая ценность пивных дрожжей [6]

Table 2. Content of essential amino acids and biological value of brewer's yeast

\begin{tabular}{|c|c|c|c|c|}
\hline $\begin{array}{l}\text { Незаменимая } \\
\text { аминокислота }\end{array}$ & $\begin{array}{c}\text { Содержание } \\
\text { аминокислоты } \\
\text { г/100г белка }\end{array}$ & $\begin{array}{c}\text { Содержание } \\
\text { НАК в белке } \\
\text { (ФАО/ВОЗ) }\end{array}$ & $\begin{array}{c}\text { Аминокислотный } \\
\text { скор, \% }\end{array}$ & $\begin{array}{c}\text { Биологическая } \\
\text { ценность, \% }\end{array}$ \\
\hline Валин & 3,56 & 5,0 & 72,0 & \multirow{8}{*}{82,2} \\
\hline Изолейцин & 3,37 & 4,0 & 92,2 & \\
\hline Лейцин & 2,63 & 7,0 & 33,4 & \\
\hline Лизин & 6,43 & 5,5 & 114,9 & \\
\hline $\begin{array}{l}\text { Метионин + } \\
\text { цистин }\end{array}$ & 3,96 & 3,5 & 103,9 & \\
\hline $\begin{array}{l}\text { Фенилаланин } \\
+ \text { тирозин }\end{array}$ & 6,74 & 6,0 & 104,7 & \\
\hline Треонин & 1,40 & 4,0 & 26,0 & \\
\hline Триптофан & 0,78 & 1,0 & 78,0 & \\
\hline
\end{tabular}

Как видно из данных табл. 2, содержание большей части незаменимых аминокислот в остаточных пивных дрожжах приближено к содержанию, рекомендованному ФАО/ВОЗ, при этом показатели аминокислотного скора свидетельствуют о высокой биологической ценности белка дрожжей, равной 82,2 \%.

В процессе брожения пивного сусла на поверхностях дрожжевых клеток сорбируются специфические вещества, переходящие в сусло из хмеля, которые придают выраженную горечь пивным дрожжам. Этот привкус - основная причина, которая препятствует широкому использованию данного вторичного продукта, ценного по химическому составу, в пищевой промышленности. По химической природе основные виды горечей являются полимерами и представляют собой сочетание кислых веществ и смол. Основная горечь обусловлена наличием в дрожжевой биомассе изо- $\alpha$-кислот [7].

Для снижения выраженности горечи в остаточных пивных дрожжах были проведены промывания их водой в соотношении 1:2 (табл. 3).

Таблица 3. Количество горечи в остаточных пивных дрожжах

Table 3.Amount of bitterness in residual brewer's yeast

\begin{tabular}{|l|c|}
\hline \multicolumn{1}{|c|}{ Исследуемый объект } & Количество горечей, BU* \\
\hline Остаточные пивные дрожжи (до отделения сусла) & 45,1 \\
\hline Остаточные пивные дрожжи (после отделения сусла) & 34,9 \\
\hline Остаточные пивные дрожжи (после 1 промывки) & 28,8 \\
\hline Остаточные пивные дрожжи (после 2 промывки) & 20,7 \\
\hline Остаточные пивные дрожжи (после 3 промывки) & 18,1 \\
\hline
\end{tabular}

1 BU* - международная единица измерения горечи, равная одной части изогумулона на миллион кислоты, получаемой из хмеля. 
Данные, представленные в табл. 3, позволяют сделать вывод, что предварительное отделение дрожжевой биомассы от пивного сусла и последующая трехкратная промывка дрожжей водой позволяют уменьшить содержание горечей в 2,4 раза.

В процессе гидролиза под влиянием ферментов или высокой температуры происходит расщепление белков на более простые соединения с появлением низкомолекулярных водорастворимых продуктов деградации (три-, дипептиды и аминокислоты), которые определяются методом аминного азота (ГОСТ 7635) и свидетельствуют о степени гидролиза белков (табл. 4).

Таблица 4. Степень гидролиза остаточных пивных дрожжей (ферментативный гидролиз), определяемая по содержанию аминного азота

Table 4. Degree of hydrolysis of residual brewer's yeast (enzymatic hydrolysis), determined by the content of amine nitrogen

\begin{tabular}{|c|l|c|c|}
\hline $\begin{array}{c}\text { Количество } \\
\text { промывок } \\
\text { дрожжей }\end{array}$ & $\begin{array}{c}\text { Ферментный } \\
\text { препарат }\end{array}$ & $\begin{array}{c}\text { Содержание } \\
\text { аминного азота } \\
\text { перед гидролизом, } \\
\text { мг / 100 г }\end{array}$ & $\begin{array}{c}\text { Содержание } \\
\text { аминного азота } \\
\text { после гидролиза, } \\
\text { мг/ 100 г }\end{array}$ \\
\hline 0 & Alcalase & & 59 \\
\hline 0 & Protomex & \multirow{2}{*}{19} & 34 \\
\hline 3 & Alcalase & & 147,8 \\
\hline 3 & Protomex & & 121,4 \\
\hline
\end{tabular}

Из данных табл. 4 видно, что ферментативный гидролиз промытых остаточных пивных дрожжей позволяет повысить степень гидролиза белка в 6,3-7,7 раза, что отражается в росте концентрации аминного азота в гидролизуемой суспензии. Низкую степень гидролиза в непромытых дрожжах можно объяснить присутствием горьких веществ хмеля на клеточных оболочках дрожжей, которые ингибируют ферментолиз, однако эти вещества вымываются при промывке и тем самым повышается степень деградации белков. Показатели степени гидролиза белка в остаточных промытых и непромытых дрожжах при использовании высокотемпературного способа гидролиза приведены в табл. 5.

Таблица 5. Степень гидролиза остаточных пивных дрожжей (термический гидролиз), определяемая по содержанию аминного азота

Table 5. Degree of hydrolysis of residual brewer's yeast (thermal hydrolysis), determined by the content of amine nitrogen

\begin{tabular}{|l|c|c|}
\hline \multicolumn{1}{|c|}{ Исследуемый объект } & $\begin{array}{c}\text { Содержание аминного } \\
\text { азота перед гидролизом, } \\
\text { мг/ 100 г }\end{array}$ & $\begin{array}{c}\text { Содержание аминного } \\
\text { азота после гидролиза, } \\
\text { мг / 100 г }\end{array}$ \\
\cline { 1 - 1 } $\begin{array}{l}\text { Остаточные пивные дрожжи } \\
\text { (до промывки) }\end{array}$ & 19 & 357,2 \\
\cline { 1 - 1 } $\begin{array}{l}\text { Остаточные пивные дрожжи } \\
\text { (после } 3 \text { промывки) }\end{array}$ & & 434,8 \\
\hline
\end{tabular}

На основании данных табл. 4 и 5 можно сделать вывод о том, что термический гидролиз остаточных пивных дрожжей наиболее эффективен в сравнении с 
ферментативным гидролизом дрожжей. При этом важно, что дрожжевой гидролизат в данном случае имел меньше горечей, чем при ферментативном способе получения, и горечи менее влияли на степень накопления аминного азота. Показатель аминного азота в 2,5-2,8 раз превышает его уровень в ферментированной дрожжевой суспензии. Этот факт подтверждается сравнительными данными по степени гидролиза белка, приведенными на рис. 1.

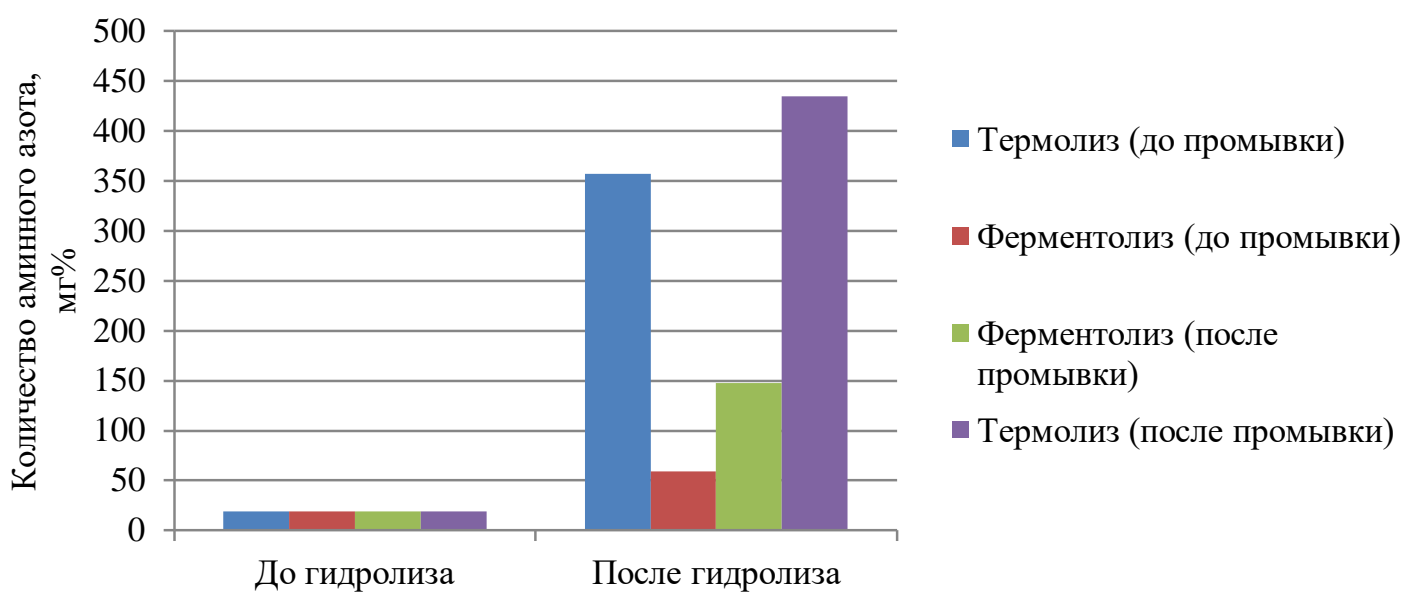

Рис. 1. Содержание аминного азота при различных способах гидролиза остаточных пивных дрожжей до и после промывки их водой Fig. 1. Content of amine nitrogen in various methods of hydrolysis of residual brewer's yeast before and after washing them with water

Из данных рис. 1 можно сделать вывод, что вещества, отвечающие за горечи в остаточных пивных дрожжах, блокируют процесс автоферментолиза, о чем свидетельствует низкое содержание аминного азота на начальном этапе гидролиза (19 мг/100 г). После 3-кратной промывки водой дрожжевой суспензии в ней активнее расщепляются белки. Видно, что термический гидролиз более эффективен, чем ферментативный, позволяя получать протеины более глубокой степени расщепления, легкоусвояемые пептидные концентраты, включающие свободные аминокислоты и полипептиды

Химический состав пивной дробины, богатой пищевыми волокнами (27\%), белками $(22,2 \%)$ и минеральными веществами $(3,6 \%)$, представлен в табл. 6

Таблица 6. Химический состав пивной дробины

Table 6. Chemical composition of brewer pellet

\begin{tabular}{|l|c|}
\hline \multicolumn{1}{|c|}{ Показатель } & Содержание, $\%$ \\
\hline Влага & 3,7 \\
\hline Белок & 22,2 \\
\hline Жиры & 2,8 \\
\hline Углеводы, в т.ч. клетчатка & 67,7, в т. ч. 27 \\
\hline Минеральные вещества & 3,6 \\
\hline
\end{tabular}


В дальнейших экспериментах была изготовлена опытная партия злаковых батончиков на основе овсяных хлопьев и пивной дробины (соотношение 1:1), яблочного пюре, кураги, меда и белкового гидролизата из остаточных пивных дрожжей термогидролиза. Рецептура батончиков представлена в табл. 7.

Таблица 7. Рецептура злаковых батончиков «Дробинка»

Table 7. Recipe for cereal bars called «Drobinka»

\begin{tabular}{|l|c|}
\hline \multicolumn{1}{|c|}{ Наименование ингредиентов } & г на 100 г продукта \\
\hline Овсяные хлопья & 30,0 \\
\hline Пивная дробина & 30,0 \\
\hline Курага & 10,0 \\
\hline Яблочное пюре & 14,5 \\
\hline Мед пчелиный & 10,0 \\
\hline Белковый дрожжевой гидролизат & 5,5 \\
\hline
\end{tabular}

Технологическая схема изготовления злаковых батончиков, названных «Дробинка», представлена на рис. 2.

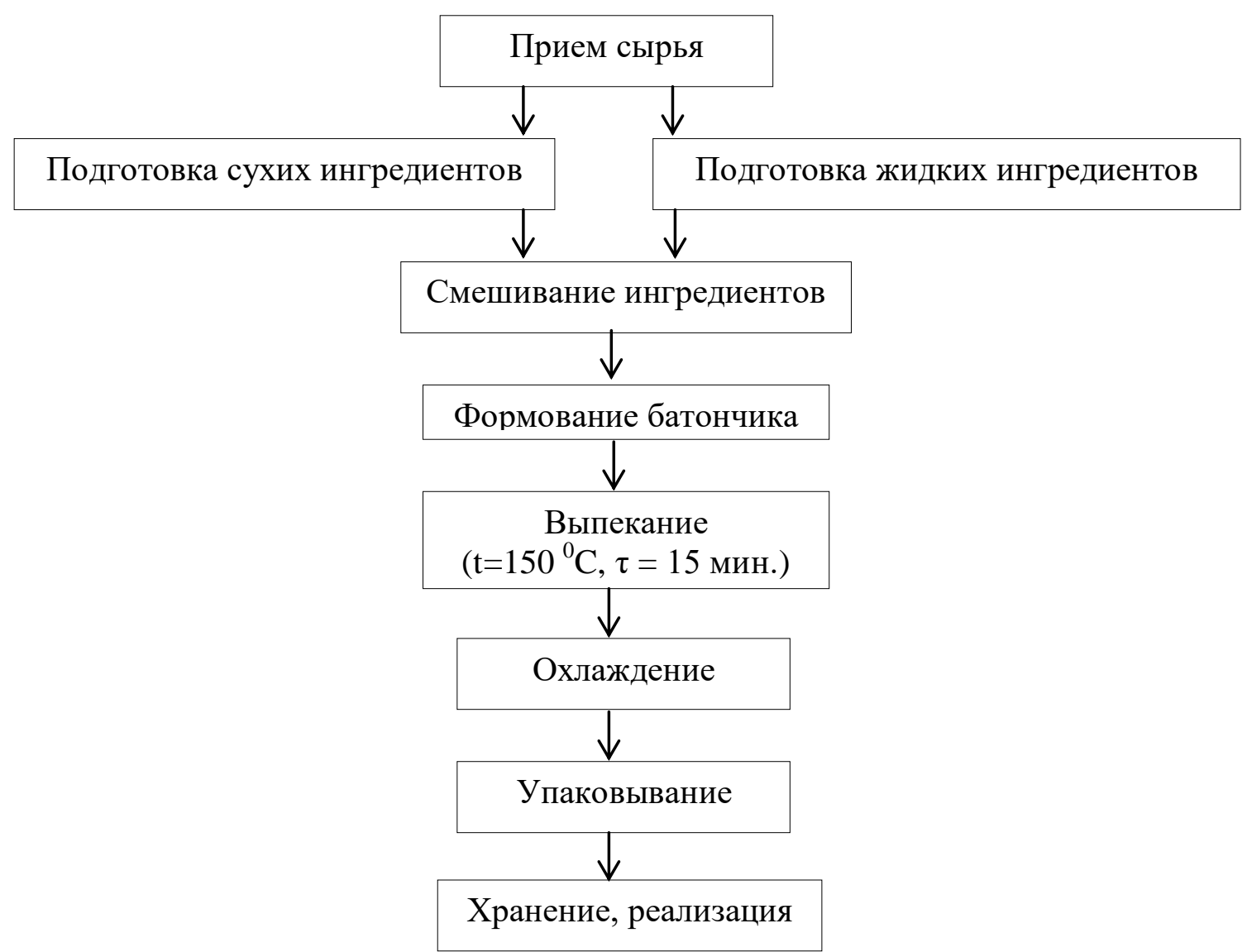

Рис. 2. Технологическая схема производства злаковых батончиков «Дробинка»

Fig. 2. Production scheme of «Drobinka» cereal bars

Химический состав нового батончика «Дробинка», разработанного с применением пивной дробины и дрожжевого гидролизата, представлен в табл. 8. 
Таблица 8. Химический состав обогащенного злакового батончика «Дробинка» Table 8 . Chemical composition of «Drobinka» cereal bars

\begin{tabular}{|l|c|c|}
\hline \multicolumn{1}{|c|}{ Показатель } & $\begin{array}{c}\text { Батончик без продуктов } \\
\text { пивоварения, \% }\end{array}$ & $\begin{array}{c}\text { Батончик на основе пивной } \\
\text { дробины и белкового } \\
\text { гидролизата, \% }\end{array}$ \\
\hline Белок & 14,6 & 26,7 \\
\hline Жиры & 3,4 & 3,5 \\
\hline Углеводы, & 64,3 & 58,0 \\
в т. ч. клетчатка & 5,6 & 13,4 \\
\hline
\end{tabular}

Из данных табл. 8 видно, что с внесением в состав батончика функциональных компонентов пивной дробины и белкового дрожжевого гидролизата почти в 2 раза увеличивается содержание белка (с 14,6 до 26,7 \%) и клетчатки (с 5,6 до 13,4 \%). Употребление 100 г такого батончика позволит удовлетворить суточную потребность человека в клетчатке на 67-89 \%, т. е. более чем на $15 \%$. Таким образом, данный продукт можно считать функциональным по содержанию клетчатки, которая, согласно требованиям ГОСТ Р 54059 - 2010 «Продукты пищевые функциональные. Ингредиенты пищевые функциональные», является биологически активным веществом, обладающим эффектом поддержания и стимулирования деятельности желудочно-кишечного тракта.

Таким образом, с применением вторичных ресурсов пивоваренных производств возможно и рационально изготавливать новый зерновой батончик, названный «Дробинка», который обладает повышенным содержанием пищевых волокон и сбалансирован по аминокислотам белка, в связи с чем его можно рекомендовать употреблять в качестве профилактического продукта при заболеваниях, связанных с нарушениями в желудочно-кишечном тракте.

\section{ВЫВОДЫ}

1. Белковый гидролизат на основе промытых остаточных пивных дрожжей, полученный с помощью высокотемпературного гидролиза, характеризуется высоким содержанием легкоусвояемого белка и низкомолекулярных пептидов, сбалансированных по содержанию незаменимых аминокислот, обладает повышенной биологической ценностью, показатель которой равен 82,2 \%.

2. Белковый гидролизат остаточных пивных дрожжей, полученный после 3-кратного промывания высокотемпературным гидролизом, имеет пониженное содержание горечей, что позволяет использовать его в качестве белкового ингредиента для обогащения углеводных закусочных продуктов, типа злаковых батончиков. Использование предлагаемой технологии гидролиза может быть рекомендовано для решения проблемы утилизации отходов пивоваренных производств.

3. На основе пивной дробины и овсяных хлопьев при их соотношении 1:1 предложены рецептура и технология злаковых батончиков, обогащенных белковым гидролизатом остаточных пивных дрожжей; готовые изделия отличаются повышенным содержанием белка (26,7 \%), а употребление 100 г батончиков позволят удовлетворить суточную потребность в клетчатке на 67-89 \%. Новый батончик является функциональным по содержанию пищевых волокон и может быть рекомендован к употреблению широким слоям населения в качестве белковоуглеводной закуски и для профилактики нарушений в пищеварительном тракте. 


\section{СПИСОК ИСПОЛЬЗОВАННЫХ ЛИТЕРАТУРНЫХ ИСТОЧНИКОВ}

1. Дадашев, М. Н. Экологически безопасная технология переработки отходов пивоварения / М. Н. Дадашев [и др.] // Пиво и напитки. - 2011. - №. 5. C. $18-21$.

2. Юскина, О. Н. Разработка биотехнологического способа получения препаратов белка из биомассы дрожжей Saccharomyces cerevisiae на основе направленного ферментативного гидролиза клеточных стенок: дис. ... канд. биол. наук: 03.0023 / Юскина О. Н. - Москва, 2008. - 171 с.

3. Кораблин, Р. В. Разработка и применение обогатителя из пивной дробины и остаточных пивных дрожжей: дис. ...канд. техн. наук: 05.18.07; 05.18.01 / Кораблин Р. В. - Воронеж, 2003. - 168 с.

4. Гонсалес, Р. Б. Применение остаточных пивных дрожжей на территории Кубы как добавки против очерствения хлеба: дис. ...канд. техн. наук: 05.18.07; 05.18.01 / Гонсалес Р. Б. - Краснодар, 2003. - 187 с.

5. Доценко, О. Н. Разработка технологий получения автолизата и белковой добавки из пивных остаточных дрожжей и их использование при производстве вареных колбас: дис. ...канд. техн. наук: 05.18.07 / Доценко О. Н. - Ставрополь, 2003. $-210 \mathrm{c}$.

6. Алехин, Ю. Н. Перспективы использования высушенных пивных дрожжей и кормов на их основе в животноводстве / Ю. Н. Алехин // Технологии пищевой и перерабатывающей промышленности. АПК - продукты здорового питания. - 2014. - № 2. - С. 7-12.

7. Куцакова, В. Е. Разработка технологии удаления горечи из отработанных пивных дрожжей / В. Е. Куцакова // Известия высших учебных заведений. Пищевая технология. - 2012. - Т. 328. - № 4. - С. 67-69.

\section{REFERENCES}

1. Dadashev M. N. Ekologicheski bezopasnaya tekhnologiya pererabotki otkhodov pivovareniya [Environmentally safe technology of brewing waste recycling]. Pivo i napitki, 2011, no. 5, pp. 18-21.

2. Yuskina O. N. Razrabotka biotekhnologicheskogo sposoba polucheniya preparatov belka iz biomassy drozhzhey Sacsharomyces cerevisiae na osnove napravlennogo fermentativnogo gidroliza kletochnykh stenok. Diss. kand. biol. nauk [Development of a biotechnological method for obtaining protein preparations from Saccharomyces cerevisiae yeast biomass based on directed enzymatic hydrolysis of cell walls. Dis. cand. biol. sci.]. Moscow, 2008, 171 p.

3. Korablin R. V. Razrabotka i primenenie obogatitelya iz pivnoy drobiny $i$ ostatochnykh pivnykh drozhzhey. Diss. cand. biol. nauk [Development and application of an enriching agent made of brewer pellet and residual brewer's yeast. Dis. cand. biol. sci.]. Voronezh, 2003, 168 p.

4. Gonsales R. B. Primenenie ostatochnykh pivnykh drozhzhey na territorii Kuby kak dobavki protiv ocherstveniya khleba. Diss. cand. tekhn. nauk [The use of residual brewer's yeast in Cuba as an additive against bread hardening. Dis. cand. techn. sci.]. Krasnodar, 2003, 187 p. 
5. Dotsenko O. N. Razrabotka tekhnologiy polucheniya avtolizata i belkovoy dobavki iz pivnykh ostatochnykh drozhzhey i ikh ispol'zovanie pri proizvodstve varenykh kolbas. Diss. kand. tekhn. nauk [Development of technologies for obtaining autolysate and protein additive from beer residual yeast and their use in the production of cooked sausages. Dis. cand. techn. sci.]. Stavropol', 2003, 210 p.

6. Alekhin Yu. N. Perspektivy ispol'zovaniya vysushennykh pivnykh drozhzhey $i$ kormov na ikh osnove $\mathrm{v}$ zhivotnovodstve [Prospects for the use of dried brewer's yeast and feed based on them in animal husbandry]. Tekhnologii pishchevoy i pererabatyvayushchey promyshlennosti. APK - produkt zdorovogo pitaniya. 2014, no. 2, pp. 7-12.

7. Kutsakova V. E. Razrabotka tekhnologii udaleniya gorechi iz otrabotannykh pivnykh drozhzhey [Development of technology for removing bitterness from used brewer's yeast]. Izvestiya vysshikh uchebnykh zavedeniy. Pishchevaya tekhnologiya. 2012, no. 4, pp. 67-69.

\section{ИНФОРМАЦИЯ ОБ АВТОРАХ}

Казимирова Екатерина Андреевна - Калининградский государственный технический университет; аспирант кафедры пищевой биотехнологии;

E-mail: kazimirova_kat@mail.ru

Kazimirova Ekaterina Andreevna - Kaliningrad State Technical University;

Post-graduate student; Department of Food Biotechnology;

E-mail: kazimirova_kat@mail.ru

Мезенова Ольга Яковлевна - Калининградский государственный технический университет; доктор технических наук; профессор; зав. кафедрой пищевой биотехнологии; E-mail: mezenova@klgtu.ru

Mezenova Olga Yakovlevna - Kaliningrad State Technical University; Doctor of Technical Sciences; Professor; Head of the Department of Food Biotechnology;

E-mail: mezenova@klgtu.ru

Шендерюк Владимир Ильич - Калининградский государственный технический университет; доктор технических наук; профессор кафедры технологии продуктов питания; E-mail: 12op@klgtu.ru

Shenderyuk Vladimir Il'ich - Kaliningrad State Technical University; Doctor of Technical Sciences; Professor at the Department of Food Products Technology; E-mail: 12op@klgtu.ru 